\title{
Digital Challenges on the Norwegian Media Scene
}

\author{
Rune Ottosen \& Arne H. Krumsvik
}

\begin{abstract}
This article summarises findings from a research project on the digitisation of Norwegian newsrooms, analysing trends in the industry and changes in user-habits. Findings suggest that most journalists are positive about the digitisation of the newsroom but fear that cutbacks in staff will prevent them from exploiting the potential of the new technology. They also fear that too much focus on technical skills will leave less space for critical journalism. Findings also suggest a correlation between resources used to develop the online edition and the perceived ethical standards of the content. More online journalism leads to a higher degree of scepticism among the readers. There are two different justifications for using resources on the online edition. Some newspaper executives hope to use the online edition to recruit new readers to the paper edition while another group hopes to develop the breadth of market service through a portfolio of publishing platforms.
\end{abstract}

Keywords: digital media; multimedia journalism; Norwegian news market; online newspaper

\section{Introduction}

Norway was among the first countries to connect to the network we know today as the Internet, ${ }^{1}$ and according to Jupiter Research, ${ }^{2}$ Norway is one of the most digitally sophisticated markets in Europe. Eighty per cent of the population over 12 years of age uses the Internet regularly. ${ }^{3}$ Of the top ten national sites, five are traditional news organizations affiliated to newspapers and broadcasters, with the online newspaper VG.no as the market leader. The other five are portals and search sites. ${ }^{4}$ This dominance of national newspapers in the online industry makes Norway a deviant case.

The current article presents findings from a research project on digitization and editorial change in Norway ${ }^{1}$. After the literature review, we will proceed backwards in the value chain (Porter 1996), first presenting a historical overview of online publishing in Norway, before discussing some key problems related to quality and editing of online publications, and then finally the role of journalists in the new environment for news production.

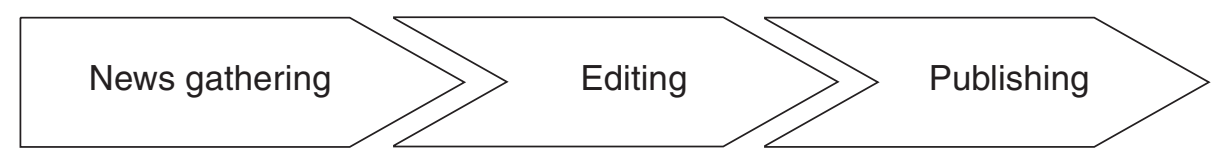




\section{Literature Review}

As traditional newspapers and broadcasters are being analysed as cross-media institutions (Boczkowski 2004, Deuze 2004, Moe \& Syvertsen 2007, Petersen \& Rasmussen 2007, Singer 2004), and interest in technology and journalism practices has increased (Cottle \& Ashton 1999, Lund 2003, Pavlik 2001), a recent stream of research across these micro- and meso-levels analyses the "gap between, on the one hand, online journalists' perceptions of the Internet's potential and, on the other hand, the actual use of interactive features" (Deuze, Neuberger, \& Paulussen 2004). The network features and interactivity capabilities of the Internet were seen as triggers for a revolution bringing "a fundamental transformation" of journalism back to its original public service rationale (Pavlik 2001, p. xi). However, surveys and comparative content analysis have demonstrated the lack of interactivity, multimedia, and participatory journalism (Kenney, Gorelik, \& Mwangi 2000; Matheson 2004, Schroeder 2004, Van Der Wurff \& Lauf $2005)$ in online news media.

Investigating how online journalists deal with interactivity in their daily working routines and the rationale behind the development of interactive options on online news sites, Domingo (2008) argues for the need to understand the underlying "technological utopianism" as a natural historical antecedent of innovation. He understands what he labels "online journalism myths" as a socially-constructed discourse shaped in the historical context of the social adoption of the Internet and the crisis of the social role of journalism in the mid-90s. However, his case study of five Catalonian newspapers shows that the myth has proven to be very pervasive and constant. Furthermore, news workers across the cases were very homogeneous in their justifications for why their products had not yet developed all the promise of the myth; they blamed their lack of resources. The inertia of the traditional newsroom culture giving priority to immediacy shaped a production model that is not likely to change despite being given more resources. Audience participation was perceived as a problem rather than as a benefit for the news product. The innovative edge of the online news operations was found in special coverage of events, outside the daily rhythm of work.

In his study of US online newspapers, Boczkowski (2004) also states that materiality matters in online newsrooms. He found that they had merged old methods of print with the Internet's new potential in an ongoing process in which different combinations of initial conditions and local contingencies led to divergent trajectories. The online news ventures of traditional newspapers tended to proceed more slowly and in a more conservative fashion than in organizations less tied to traditional media. However, the cumulative transformation over two decades was found to be remarkable. He highlighted the value of history, locality, and process in the study of new media, and emphasized the need to pay attention to the production process in order to avoid the risk of attributing either cultural or technological necessity to locally contingent outcomes. Remediation and interactivity were found to be enacted to varying degrees across the three cases as a result of different combinations of the local contingent factors.

This is the background for our first research question:

RQ1: How does digital development have an impact on editorial routines in the newsroom? 
Organization and access to resources are also a central theme of other studies. Hjeltnes et al. (2007), referring to Dailey et al.'s (2005) “continuum", found the online and print newsrooms in Norwegian media organizations to be integrated to varying degrees. Through case studies of four media organizations, Singer (2004) argues that cultural and technical differences and a lack of necessary training block convergence, while Quinn (2005) argues for a "fundamental dichotomy" inherent in convergence journalism, whether news executives and journalists are embracing convergence for business reasons or to improve journalism. As many as six out of ten Scandinavian editors state that the Web is the publishing platform that has the greatest need for product development. But it's an open question whether the necessary resources are made available for the editors to meet the digital challenges. Seven out of ten editors say that less than 30 per cent of development resources go to the Net (Hjeltnes et al. 2010).

According to Mitchelstein and Boczkowski (2009), there is a need for new media studies that can help to bridge the gap between scholars who study either production or consumption. The research project presented here contributes to bridging this gap, by attempting to understand the dynamics of online journalism and addressing dilemmas related not only to the study of journalism, but also to the larger field of communication and media studies.

The case under scrutiny is the online news industry in a highly digitally sophisticated country. While this condition is similar for the industry as a whole, we see from the literature review that other conditions lead to variation in the organization of online activities. Our second research question investigates how the deviant case of Norway affects the industry:

RQ2: To what extent can we trace a common digital development in the Norwegian media industry?

\section{Historical Overview: How Norway Became an Online Pioneer}

Dagbladet launched the first major online news operation in Norway on 10 March 1995. $V G$ published its online edition on 10 October of the same year. And even though Dagbladet re-launched a more news-focused issue the day before this, it did not stop the country's largest daily taking the lead online as well. A solid brand and interactive services were its main weapons.

Høst has kept a register of developments in the number of online newspapers in Norway since 1996, and "following a certain amount of hesitation in 1995 (only 17 newspapers were registered online by February 1996), a rapid expansion occurred in 1996. Then came three years of relatively slow growth until activities boomed once more in 2000" (Høst 2004, p. 14; our translation). This boom was echoed in the media coverage of this new area in the media landscape.

By the end of 2000, there were 157 online newspapers in Norway, and out of these 126 offered a news service as part of their output. The maturing of the online newspaper market, measured by the number of print newspapers with their own respective online editions, does not follow a classic diffusion curve, and Høst (2000) emphasizes two explanatory variables: 
If we compare the pattern of diffusion [...] with the ideal-typical S-curve for diffusion [...], it is most notably the fast growth in 1996 that does not fit. Instead of waiting to see what would happen, as many papers did in 1997-1999 [...], many were now anxious to get on board early. The explanation for this is both that they were afraid of being surpassed by the technological development ('being left on the platform as the train leaves'), and that it was possible to create a fairly decent Internet service at a low cost. (Høst 2004, p. 14; our translation)

In addition, the launch of the Internet-only 'Nettavisen.no' in 1996 made a significant impact and contributed to changing the market structure. A central part of the business idea was to function as a meta-medium in relation to newspapers. By systematically surveying and citing the most interesting stories published in the print media every day, Nettavisen, despite its limited resources and within a short period of time, was able to offer complete news coverage previously only available through the largest newspapers. Furthermore, a few self-produced stories were often quite elegantly developed to make the evening television news, hence promoting Nettavisen.

After some time, Nettavisen's breadth became a substitute for the omnibus print paper instead of promoting the original messenger of the particular piece of news. The newspapers responded by increasing their efforts in their own online editions and thus reinforced the effect.

In 1995, most newspapers asked themselves whether this was in fact a case of cannibalization, but those concerns had to be put aside in favour of looking at the realities of the competition in the market. All online papers cited each other, and the problem for print papers that wished to withhold stories from their online editions was that readers could now find the story in their online rivals, and not where it might be logical to start the search. It is the good, exclusive stories that one wishes to withhold; the problem is that these are also the stories that will be cited (Krumsvik 2006).

Scandinavia Online (SOL) was launched as a joint venture between Telenor (the national Telco) and Schibsted (the largest media group) in 1997, and became the default home page of 80 per cent of private online users. Hence it also became the most important portal of online news, but all traffic was sent to the medium of origin. The Swedish Telco Telia joined the venture, and through mergers and acquisitions, SOL became a major player in Norway, Sweden, and Denmark. The initial rationale was partly defensive in response to the expansion plans of America Online. They never became a reality, but the SOL positions in the portal and search markets were strong enough to make Yahoo! leave Scandinavia.

After the online financial crisis in 2001, Scandinavia Online was sold to the Yellow Pages operator Eniro, and Schibsted developed VG.no in Norway and Aftonbladet.se in Sweden as their main portal initiatives. Default start pages became less important for market reach, and the online newspapers in Norway developed a very strong position due to major investments as a consequence of the competition from Nettavisen.

Following the turbulence in the aftermath of the financial collapse in 2001, 2005 represented a commercial breakthrough for the online newspaper business, with the newspapers receiving more demand for advertising space than they could offer, and making high profit margins. The online activities of the largest media group, Shibsted, produced impressive figures in 2006. Revenues grew by more than 60 per cent, and these 
activities' share of the Group's operating profit (EBITDA) was 24 per cent.

The Norwegian Broadcasting Corporation launched NRK.no in 1995, offering a selection of programme-related material, but with low-key involvement in the emerging online market owing to advice from the EBU. The general online optimism leading up to the millennium, and the possibility of advertising financing by defining online activities outside the public service remit, led to a new strategy at NRK, involving online news. As the penetration of broadband access increased, the competitive advantage of the late starter was believed to be video content. However, NRK did not manage to realize this potential. The national newspapers started Web TV offerings in 2006, and the largest newspaper, $\mathrm{VG}$, also became the leading online broadcaster, much to the frustration of the nation's dominating broadcaster, NRK.

The leading commercial broadcaster, TV 2, had become a major player in online news through the purchase of the online-only Nettavisen. TV 2's strategy was to offer online video as a premium service requiring a paid subscription, and as it was the dominant player in this niche, this became a profitable venture based on on-demand news and entertainment previously aired on television.

Hence, the traditional major newspapers took the lead in the development of original multimedia news content for the web. The major online newspapers have developed into mega-sites in Norway, also providing games, entertainment, and venues for usercreated content. Their major competitors in this field are the international (e.g., USbased) players.

\section{Quality Issues}

In the historical overview we identified different strategies from various parts of the Norwegian media industry. Newspapers were early adopters, while the public broadcasters were late movers. This indicates lack of common development (RQ2). Within the newspaper industry we also find variation in strategic issues.

Newspaper executives offer two different justifications for using resources in the online edition, according to the Norwegian Online Newspaper Surveys conducted by this research project in 2005 and 2008, where readers, journalists and executives of online newspapers were asked, e.g., about strategic positioning in the new digital market and changes in their behaviour. ${ }^{8}$ Some leaders hope to use the online edition to recruit new readers to the paper edition, while another group hopes to develop the breadth of market service towards readers and advertisers through a portfolio of publishing platforms.

The latter aim seems within reach. From 2005 to 2008, the number of users claiming to spend more time on the two channels combined than they spent previously on the newspaper alone has increased from a third to a half of the online users of local and regional online newspapers.

However, there is no evidence for successful recruiting to the paper edition through online use. On average, the online product was regarded as inferior to the paper edition. In 2005, when readers were asked to grade general satisfaction on a scale from 1 to 6 (where 6 is the best score), the paper edition received an average of 4.2 and the online edition 3.7. Three years later, the paper edition was graded 4.5 and the online edition 4.0. The differences were unchanged. And the critical group of young adults was least satisfied with the online newspapers. 
Findings suggest a correlation between resources used to develop the online edition and the perceived ethical standards of the content. More online journalism leads to a higher degree of scepticism among readers. For users of city dailies, the share of sceptics rose from 14 per cent to 23 per cent between 2005 and 2008. And journalists are even more sceptical towards their own online product - while 17 per cent of users on average perceived the online standard to be inferior to the paper edition, 56 per cent of journalists were of the same opinion.

The circulation of newspapers is declining, partly as a consequence of increased Internet usage, a development the papers themselves have helped push forward. Thus, they have influenced their environment in such a way as to challenge their own core activity, while at the same time positioning themselves well in the new media. They have not succeeded, however, in finding a balanced focus between traditional and new activities. It seems as though newspaper executives find it difficult to respond efficiently to the insecurity created as a result of changes in the environment (Krumsvik 2006). In his study of the relationship between the paper version and online version, Sigurd Høst claims that the trend among small and local newspapers is that they seem to use fewer resources on the online version. The pattern in the online market is that the leading online newspapers such as $V G$ and Dagbladet increasingly develop their digital platform and also make money on online advertising, while the situation in the local newspapers is different. The trend to protect their paper version and produce less exclusive news online seems to have become stronger during the financial crisis of 2008 (Høst 2011).

How this affected the editorial routines in the newsroom (RQ1) will be discussed later in the article.

\section{Editing: Debate on User-created Content and Ethical Guidelines}

While we identified a lack of common development both within the media industry at large (newspapers vs. television) and regarding strategic issues within the newspaper industry, we also found a divide in attitudes towards user-generated content, relevant to RQ2.

Ethics are another issue related to user-generated content. In a controversy over revision of the Code of Ethics of the Norwegian Press, the Norwegian Union of Journalists demand that all content be pre-edited prior to publication, while the Association of Norwegian Editors are in favour of the contemporary practice of post-moderation.

The Code of Ethics set up by the Press Association includes a paragraph regarding online communities, stating that publishers need to inform users if the forum is not edited and that the publisher is responsible for deleting improper postings. A suggestion from a revision committee in 2005 to change the practice and to demand the editor's approval of all postings on message boards in media belonging to the Press Association failed to be implemented owing to a lack of consensus on the matter. If the majority had pushed the decision through, the major news sites, which have strong economic interests in heavily-used unmoderated and post-moderated forums, would not have complied, and this could have put the whole self-regulative system of media ethics in jeopardy (Krumsvik 2005, Lindholm 2006, Ottosen \& Krumsvik 2008). NRK also lobbied for the status quo in this process. 
When, in February 2008, Agderposten was sentenced in $\mathrm{PFU}^{9}$ for having published a rumour about soccer player Stig Inge Bjørnebye, there followed an extensive debate on editorial responsibility for the newspaper's website. In an article in Aftenposten, the leader of the Norwegian Union for Journalists, Elin Floberghagen, took issue with the Norwegian Association for Editors. She believes that the ethical code should be strengthened and that editors should take greater responsibility for debates on their websites by editing the letters before they are published online (Aftenposten 18.2 2008). The response from Nils E. Øy and Arne Jensen of the Association for Norwegian Editors was that the present ethical guidelines are sufficient to place responsibility on the editors. They also denied being against pre-edit postings, but said this had to be an independent decision in each newspaper (Aftenposten 28.2.2008).

According to the Norwegian Online Newspaper Survey of 2008, 52 per cent of journalists and 37 per cent of users were positive about pre-moderation of online debates, while 20 per cent of the journalists and 29 per cent of the users were negative. However, among users who regard the online newspaper's discussion forums to be a more important arena than traditional newspapers for exercising freedom of expression, 48 per cent of users were opposed to pre-moderation, while 33 per cent per cent were in favour.

\section{Role of Journalists in a Digital Everyday Life}

The Norwegian Union of Journalists ${ }^{10}$ conducted a survey in 2007 among $715^{11}$ journalists in digital media with a continuous deadline. ${ }^{12}$ The survey, which shed light on how digital development impacts editorial routines in the newsroom (RQ1), revealed that journalists are basically happy in their jobs. They are also enthusiastic about the opportunities offered through the new digital platforms and tools. At the same time, however, they are concerned about commercial and digital developments in the media industry. Earlier surveys, from 1992 and from 2002/2003, have revealed issues such as increased time pressure, increased stress and greater pressure to achieve results (Sørensen et al. 1993, 2005). The digital media development seems to reinforce journalists' concerns about such issues. In the survey, 63 per cent of respondents complain about extensively increased time pressure, and in addition 34 per cent respond that they felt some degree of increased time pressure. But the survey as a whole is generally positive with regard to digital developments in the news market. The main findings reveal that:

- The majority believes that digitization of the work environment contributes to a positive relationship among colleagues.

The majority believes that digitization of the work environment improves the relationship with management.

- The majority claims to have well-adapted working tools.

- The majority feels that their well-being improved in the working environment after the digital platform was introduced, while a minority says they are worse off than before.

This relative satisfaction is not without exceptions: A majority of survey participants have several suggestions for improvements in their working environment to create bet- 
ter journalism. First of all, they want better conditions for investigative reporting and better teamwork among colleagues. In short:

- They want more staff on the shifts.

- They want more discussions in the newsroom to improve the journalistic product.

- They want the opportunity to specialize and to do more in-depth work on their own stories.

- They want better procedures for feedback and evaluation from the leadership.

- They want more time for editorial cooperation with colleagues.

One of the concerns expressed in the survey relates to the relationship between productivity and quality. Similar concerns are also revealed in studies looking at news production in Sweden and England (Witschge \& Nygren 2009). There is no doubt that there is strong pressure in the newsroom to attract as many hits from readers as possible, and the classic journalistic ideals including use of multiple sources and checking of sources are under pressure in online journalism. There is a danger that the increase in quantity comes at the expense of quality. Stress and production pressures are a direct challenge to the working environment and to the quality of journalism in general. Reports from a research project based on participatory observation in the newsroom confirm this. Astrid Gynnhild has documented the fact that many journalists skip their lunch break in order to maintain the expected number of hits. She also reveals that journalists check the hit-rating often during their shifts and admit in interviews that this has an impact on their priorities. There is a temptation to publish stories that produce hits and increase the traffic, such as titles about sex and celebrities. They acknowledge the dilemma: that such easy solutions to the increase in traffic may undermine the quality of the product in the long run (Gynnhild 2008).

\section{Time, For Better or Worse}

Journalists expect stress when they go to work. The speed at which they work and the amount of varied tasks performed at high speed are some of the things that seem to attract young people to the newsroom (Bjørnsen et al. 2007). Time pressure and high production levels are partly factors that make journalism attractive, but the balance between the amount of production and the time of production must be reasonable. It is often a chaotic and turbulent life, and that creates enthusiasm among reporters, but there is also the fear among journalists in the digital environment that time pressure may harm the quality of the journalistic product, and an additional source of frustration is that the technology sometimes fails. Having many tasks, but being unable to solve technological problems themselves, is stressful and creates dissatisfaction among reporters. The problem increases when the level of ambition is higher than that which journalists feel is realistic. The possibility of losing face publicly when mistakes occur is another source of stress, and because many journalists produce articles with by-lines, they are vulnerable to such humiliation.

The majority of respondents in the survey feel that the workload has increased as a result of the new working practices and digital tools. At the same time, more than half 
say that the demand for more productivity decreases the quality of their work. As many as 58 per cent say that, in addition, they are given more tasks than they have time to deal with during a shift. In a control group in a survey among journalists in other media, only 42 per cent voiced that complaint, and in a survey conducted by Statistics Norway (SSB) in 2006 among employees regardless of industry, only 28 per cent say that they do not have time to perform their work properly. This shows that journalists who work on a digital platform have a particularly vulnerable work environment when it comes to pressure and workload.

Journalists who work on digital platforms complain that they do more than they are paid for, and 51 per cent say they feel pressured to provide more than their salary warrants, whereas the corresponding figure in the control group is 40 per cent. For some reason, employers think that journalists who work digitally should be more "flexible", as 76 per cent say they feel they are expected to be more flexible about hours and to work more overtime. The survey among digital journalists also shows that there is inadequate training in the media houses, with 29 per cent saying they are forced to undertake tasks outside their competence. Here, the contrast with the rest of the workforce is even more striking - only 3 per cent in the SSB survey report that they "need to perform daily tasks without enough training".

\section{Mental and Physical Stress}

It is mentally stressful to work on a multimedia platform, and 43 per cent agree with this statement, partially or completely, while 15 per cent say that in the course of the past six months, they have been bothered by work-related nervousness and anxiety, and 16 per cent complain of burnout. Neck, shoulder and upper back problems affect 37 per cent, and 31 per cent report headaches. On the other hand, only 15 per cent of respondents to the SSB survey claim to have neck, shoulder and upper back problems, and only 3 per cent in the SSB survey report headaches. Again we see that journalists working in a digital environment are more vulnerable than others are.

\section{Reorganization Syndrome}

Multimedia production and news production with continuous deadlines have led to sizeable and repeated reorganization in large and small media companies. The survey responses provided by leaders give rise to questions about how successful the reorganization of newsrooms has been. It may appear that media company leaders tend to use trial-and-error methods when trying to adapt the editorial routine to a new technological reality. One answer to the increased workload has been to introduce more mid-level leaders, but this has not been very successful and seems to have created new problems of lack of communication, even though the opposite was the intention. The survey results indicate that, in practice, more mid-level leaders means fewer people in active news production - in itself a new source of added stress. The conclusion is that the organization of multimedia media news production has potential for improvement, for it is not good enough that only half of respondents are satisfied with how work is organized in their local newsrooms. 


\section{Problems with Multimedia Production}

Those who work for multimedia platforms are particularly vulnerable to stress. One respondent put it like this: "It takes more time when you work with multimedia news production. It takes more time to make radio, TV and online than just radio - and we must adjust to the working tools in different media." Another says: "Our newsroom is influenced by the hunt for unique users, and we have little opportunity to work with long-term plans and strategies in developing stories." The combination of cut-backs and more tasks is not good for the quality of the work. One respondent explains it as follows: "I'm quite good (at my work). These tasks have become more and more demanding, but we have fewer people than before". A journalist working in broadcasting says: "The production is running on 120 per cent but we are far too few staff when we have to fill so much time on the air."

A final statement shows that staff shortage is a problem in many newsrooms: "In summary, too much to do every day. Too much work. Too few employees in the division ... Had I been younger, I would have found something else to do. If this continues, it will have implications for recruitment to the profession." (All quotes from NJ 2008 in Ottosen and Krumsvik, 2008).

\section{The Quality Threatened - A Potential Ethical Problem?}

A majority of the respondents believe the quantity of production is given priority at the expense of quality.

- 73 per cent of respondents believe that the requirement for high quantity weakens the quality of the editorial product.

- A majority said they would use more sources if only they had the time, and 75 per cent say they use fewer sources than they would like to use.

All Norwegian journalists and editors organized in the Norwegian Press Association are committed to respecting the ethical guidelines expressed in the code of ethics (Vær Varsom-plakaten and Tekstreklameplakaten), which defines some criteria for journalistic quality. In light of the result from this survey, one might ask whether some of these guidelines are under pressure. One such issue is the requirement to use a diversity of sources. Another is the possibility of resisting pressure from a growing information industry constantly trying to influence the news agenda (Allern 1997).

\section{Concluding Remarks}

We know that there will be many changes in the newspaper industry and in online journalism, but we must be careful about predicting exactly in what way these changes will occur. It took ten years from the establishment of the first online newspapers in 1995 until we saw a commercial breakthrough in online publishing, and while Norway was an online pioneer, the present research reveals a lack of common strategies in the Norwegian media industry.

The launch of Nettavisen.no was a key event, however, and the history of the site illustrates some key developments. It started as an independent rebel - based on theft 
from other sources - and a simple business updating the news on its own website. Other media felt forced to follow, driven more by fear of being left behind on the platform than by any clear business idea. Around the turn of the millennium, owners were willing to throw money at online newspapers without having a proper business model in mind, and the result was a dramatic fall in the market in 2001, with all those who had been declared geniuses now looking more like idiots (Krumsvik 2006b: 13). Nettavisen then became the promotion site for a traditional media operation (TV 2). This experience of volatility is still affecting the industry, especially after a new recession hit the market in 2008. There is now insecurity and doubt among investors and editors about how to move forward in the market. Nettavisen is downsized and controlled by TV 2's owners as a stand-alone product.

Key findings in the Norwegian Online Newspaper Survey of 2008 prove that newspapers have been successful in getting users to spend more time on their services across platforms. They have not been successful, however, in developing attractive online products for young adults. Young journalists and journalism students are sceptical about choosing a career in online journalism, despite the fact that most jobs announced nowadays are in online and multimedia journalism (Bjørnsen, Hovden and Ottosen 2007).

Users are less satisfied with the online product than with the traditional paper edition. And more online journalism increases scepticism regarding the ethical standards of the online product. Journalists are less content with the online editions than users are, and even more sceptical towards online standards and practices. Because the relationship between journalistic work and technological progress is essential to development of the role of journalists (Ottosen 2004), the growth of online journalism will have a major impact on editorial routines in the newsroom and the future of journalism.

\section{Notes}

1. NORSAR (Norwegian Seismic Array) at Kjeller was one of about 50 nodes of ARPANET in 1975 (Rasmussen, 2007).

2. Jupiter Research: "European Digital Life Index, 2005”, EUH05-C01.

3. TNS InterTrack, March 2007.

4. TNS Metrix, December 2007.

5. DTT utilizes digital technology to provide a greater number of channels and/or better quality pictures and sound using aerial broadcasts to a conventional antenna instead of a satellite dish or cable connection.

6. Allmennkringkastingsregnskapet 2005.

7. Stortingsmelding No. 30 (2006-2007), p. 85.

8. More about the Norwegian Online Newspaper surveys on http://krumsvik.com/OnlineNews/

9. The Ethical Board of the Norwegian Press Association.

10. The Norwegian Union of Journalists has 9500 members and organizes more than 95 per cent of all Norwegian journalists.

11. The response rate was 49.5 per cent. This is a bit low, but the sample includes all members of the Norwegian Union of Journalists working on digital and multimedia platforms. We thus believe that the survey offers an adequate picture of those working with digital news production.

12. The survey was first presented in Norwegian through the authors' publication (Ottosen and Krumsvik, 2008).

Findings from this project are also presented in Ottosen, R., \& Krumsvik, A.H. (2010) Digitization and Editorial Change in Online Media. Findings from a Norwegian Research Project. Nordicom Information, 32(4), 17-26. 


\section{References}

Allern, S. (1997) Når kildene byr opp til dans. Oslo: Pax forlag.

Bjørnsen, G. (2005) Journalister i støpeskjeen? Om holdninger til yrke og tdanning blant journaliststudentene i Volda og Oslo. Hio Rapport 52003 nr. 23.

Bjørnsen, G., Hovden, J., \& Ottosen (2007) Fra valp til vakbikkje. En longitudinell undersøkelse av norske journaliststudenter, Nordicom Information 29(4), 57-69.

Boczkowski, P.J. (2004) Digitizing the News: Innovation in Online Newspapers. Cambridge, Massachusetts: The MIT Press.

Cottle, S., \& Ashton, M. (1999) From BBC Newsroom to BBC Newscentre - On Changing Technology and Journalist Practices, Convergence. The International Journal of Research into New Media and Technologies, 5(3), 22-43.

Dailey, L., Demo, L., \& Spillman, M. (2005) The Convergence Continuum: A Model for Studying Collaboration between Media Newsrooms, Atlantic Journal of Communication, 13(3), 150-168.

Deuze, M. (2004) What is Multimedia Journalism?, Journalism Studies, 5(2), 139-152.

Deuze, M., Neuberger, C., \& Paulussen, S. (2004) Journalism Education and Online Journalists in Belgium, Germany, and the Netherlands, Journalism Studies, 5(1), 19-29.

Domingo, D. (2008) Interactivity in the Daily Routines of Online Newsrooms: Dealing with an Uncomfortable Myth, Journal of Computer-Mediated Communication, 13(3), 680-704.

Gynnild, A. (2008) Klikket som tilbakemelding, in Ottosen, R., \& Krumsvik, A.H. (eds.) (2008) Journalistikk $i$ en digital hverdag. Kristiansand: IJ forlaget/Høyskoleforlaget (Norwegian Academic Press).

Hjeltnes, G., Olsen, R., \& Bech-Karlsen, J. (2007) Rapport fra ti norske mediehus. En studie av flermediale løsninger. Oslo: Handelshøyskolen BI og Institutt for Journalistikk.

Hjeltnes, G., Beck-Karlsen J., \& Olsen, R. (2010) Mediehus 2010. Gamle plattformer dør og nye oppstår. En oppsummering av sentrale funn i mediehusundersøkelsen 2010. www.mediehus.org

Høst, S. (2004) Avisåret 2003 - Farvel til fullformatet? Revidert utgave. Rapport 2/2004. Fredrikstad: Institutt for Journalistiskk

Høst, S. (2011) Avisåret 2010. Rapport nr. 18. Møreforskning/Høgskolen I Volda.

Kenney, K., Gorelik, A., \& Mwangi, S. (2000) Interactive Features of Online Newspapers, First Monday, 5(1). Krumsvik, A.H. (2005) Presse-nei til nettdebatt, Dagens Nceringsliv (20.06.05).

Krumsvik, A.H. (2006) The Strategic Role of Online Newspapers, Nordicom Reveiw, 27(2).

Krumsvik, A.H. (2006b) Nettavisen 10 år etter-hva har skjedd, in Rune Ottosen, R., \& Ytterstad, A. (eds) HiO rapport nr. 92006.

Krumsvik, A.H. (2009) The Online News Factory: A Multi-lens Investigation of the Strategy, Structure, and Process of Online News Production at CNN and NRK. Ph.D. Thesis, University of Oslo.

Lindholm, M. (2006) Maskespill og nettdebatt, Nytt Norsk Tidsskrift, 23(4), 357-367.

Lund, M.K. (2003) Med "virkeligheten” som co-regissør. Universitetet i Oslo/Høgskolen i Oslo, Oslo.

Matheson, D. (2004) Weblogs and the Epistemology of the News: Some Trends in Online Jjournalism, New Media \& Society, 6(4), 443-468.

Ministry of Cultural and Church Affairs (2007a) Kringkasting i en digital fremtid. Stortingsmelding nr. 30 (2006-2007). Oslo.

Ministry of Cultural and Church Affairs (2007b) NRK-plakaten: "Noe foralle. Alltid" Stortingsmelding nr. 6 (2007-2008) Oslo.

Mitchelstein, E., \& Boczkowski, P.J. (2009) Between Tradition and Change. A Review of Recent Research on Online News Production, Journalism, 10(5), 562-586.

Moe, H. (2008a) Public Service Broadcasting på Internett? En komparativ analyse, in Mortensen, F. (ed.) Public service i netvarkssamfundet. Frederiksberg: Samfundslitteratur.

Moe, H. (2008b) Public Service Media Online? Regulating Public Broadcasters' InternetServices - A Comparative Analysis, Television \& New Media, 9(3), 220-238.

Moe, H., \& Syvertsen, T. (2007) Media Institutions as a Research Field. Three Phases of Norwegian Broadcasting Research, Nordicom Review, 28(Jubilee Issue), 149-167.

Norsk Journalistlag (2008) Klem, C., Odinsen, H., Molde, E., \& Askerød, M.: Norsk Journalistlagsarbeidsmiljøundersøkelse blant journalister som jobber med kontinuerlig deadline.

Ottosen (2004) I journalistikkens grenseland. Journalistrollen mellom marked og idealer. Kristansand: IJ/ Høyskoleforlaget.

Ottosen, R., \& Krumsvik, A.H. (eds.) (2008) Journalistikk $i$ en digital hverdag. Kristiansand: IJ-forlaget/ Høyskoleforlaget (Norwegian Academic Press).

Ottosen, R., \& Krumsvik, A.H. (2010) Digitization and Editorial Change in Online Media. Findings from a Norwegian Research Project, Nordicom Information, 32(4), 17-26.

Pavlik, J.V. (2001) Journalism and New Media. New York: Columbia University Press.

Petersen, A.B., \& Rasmussen, S.K. (eds.) (2007) På tvoers af medierne. Aarhus: Ajour Forlag. 
Porter, M.E. (1996) What is Strategy? Harvard Business Review, November-December, 61-78.

Quinn, S. (2005) Convergence's Fundamental Question. Journalism Studies, 6(1), 29-38.

Rasmussen, T. (2007) Kampen om Internett. Oslo: Pax.

Roppen, J. (2009) Norsk public service efter 1996, in Lund A.B., Nord, L., \& Roppen, J.: Nye udfordringer for gamle medier: skandinavisk public service i det 21. århundrede, Göteborg: Nordicom.

(Endnotes)

1Schroeder, R. (2004) Interactive Info Graphics in Europe - Added Value to Online Mass Media: A Preliminary Survey, Journalism Studies, 5(4), 563-570.

Singer, J. (2004) Strange Bedfellows? The Diffusion of Convergence in Four News Organisations, Journalism Studies, 5(1), 3-18.

Sørensen, B., \& Grimsmo, A. (1993) Arbeidsmiljøundersøkelser i medievirksomhet - kremjobb til krampa tar? Arbeidsforskningsinstituttets rapportserie 1993.

Sørensen, B., \& Grimsmo, A. (2005) Tatt av ordet. edienesforspilltil framtidens arbeidsliv. Oslo: Arbeidsforskningsinstitutt.

Tankard jr., W., \& Ban, H. (1998) Online Newspapers: Living Up to Their Potential? Paper presented at the AEJMC.

Van Der Wurff, R., \& Lauf, E. (2005) Print and Online Newspapers in Europe: A Comparative Content Analysis in 16 Countries. Amsterdam: Het Spinhuis.

Witschge, T., \& Nygren, G. (2009) Journalism A Profession Under Pressure?, Journal of Media Business Studies. 6 (1), 37-59.

Rune Ottosen, Professor in journalism, Oslo and Akershus University College of Applied Sciences, Institute for Journalism and Media Studies and Professor II in journalism at University of Nordland, rune.ottosen@hioa.no

Arne H. Krumsvik, Ph.D., Post-Doctoral Fellow, Department of Media and Communications, University of Oslo, and Associate Professor II in Media Management, Gjovik University College, GUC Media Lab, ahkrumsvik@gmail.com 